doc. dr. sc. Marko Tomljanović

Sveučilište u Rijeci, Ekonomski fakultet Rijeka, Rijeka, Republika Hrvatska

marko.tomljanovic@efri.hr

\title{
REALNA KONVERGENCIJA U ZEMLJAMA ZAPADNOGA BALKANA ${ }^{1}$
}

Primljen: 23. kolovoza 2019.

Prihvaćen: 15. prosinca 2019.

Pregledni rad

\section{Sažetak}

Konvergencija predstavlja jedan od ključnih prioriteta europske ekonomske integracije, sa ciljem smanjivanja razvojnih razlika između regija. Problem istraživanja proizlazi iz gospodarskih, političkih, društvenih i ostalih ograničenja u zemljama Zapadnoga Balkana, a koje usporavaju njihov napredak te ostvarenje punopravnoga članstva u EU, a što predstavlja njihov ključni dugoročni strateški cilj. Cilj istraživanje je znanstveno utemeljeno analizirati i prezentirati teorijske temelje konvergencijskih procesa te provesti analizu dosadašnjega ostvarenja realne konvergencije u zemljama Zapadnoga Balkana. Provedenim istraživanjem su utvrđena pozitivna kretanja u promatranim zemljama u vidu povećanja BDP-a per capita, dinamike gospodarskoga rasta te sve veća orijentacija na suvremene pokretače gospodarskog rasta. Ipak, u ovim zemljama još uvijek dominiraju problemi vezani za tržište rada, životni standard i ostvarenje produktivnosti. Postojeća situacija predstavlja izazov za nositelje gospodarske i političke moći u definiranju sveobuhvatnih politika i strukturnih reformi u cilju osiguranja uvjeta za ostvarenje konvergencije prema razvijenim zemljama članicama EU.

Ključne riječi: $E U$, realna konvergencija, Zapadni Balkan

JEL: F15, F63

1 Ovaj rad je nastao u sklopu znanstvenoga projekta pod naslovom Ulaganje u istraživanje i razvoj i konkurentnost Republike Hrvatske i zemalja Zapadnoga Balkana. Projekt je financira od strane Ekonomskoga fakulteta Sveučilišta u Rijeci. 


\section{UVOD}

Temeljni cilj EU od njezina nastanka podrazumijeva smanjivanje razvojnih razlika između regija te poticanje razvoja u najslabije razvijenim regijama. Pritom, poseban naglasak je stavljen na ruralna područja, područja koja su pogođena industrijskim promjenama te regije koje se suočavaju sa prirodnim i demografskim problemima. U okviru kohezijske politike za razdoblje 2014.-2020. godine, a koja zauzima šire područje od regionalne politike, EU definira tri ključne vrste regija, $\mathrm{i}$ to manje razvijene regije ${ }^{2}$, regije $\mathrm{u}$ tranziciji ${ }^{3}$ te razvijene regije ${ }^{4}$ (Eurostat (12), 2019). Zemlje Zapadnoga Balkana, koje se uključuju u europske integracijske procese ulaze u skupinu najmanje razvijenih područja, s nužnošću pokretanja razvojnih procesa (Eurostat (13), 2019).

Konvergencijski procesi se oduvijek prožimaju sa produbljivanjem i proširivanjem europske ekonomske integracije. Bongardt i Torres (2013) ističu kako je jedan od ključnih motiva uključivanja zemalja u europske integracijske procese sustizanje životnoga standarda u onima razvijenijima. Konvergencija je od samih početaka prisutna i u zakonodavnim aktima različitih stupnjeva europske integracije. Ugovor o Europskoj uniji iz 1992. godine navodi nužnost jačanja gospodarskog jedinstva i osiguravanja harmoničnog razvoja, u cilju smanjivanja razvojnih razlika između različitih regija. Također, reformama u sklopu Lisabonskog ugovora iz $2007^{5}$. godine, Ugovor o funkcioniranju EU (UFEU) dobiva poglavlje pod naslovom Gospodarska, društvena i teritorijalna kohezija. Članak 158. UFEU kao ključni cilj EU ističe približavanje razvojnih razlika među regijama te smanjenje zaostajanja najmanje razvijenih regija. Isto tako, članak 174 UFEU navodi kako će Unija u svrhu ostvarenja harmoničnoga razvoja „poticati, razvijati i slijediti akcije koje vode jačanju njezine ekonomske, socijalne i teritorijalne kohezije“.

Problem istraživanja proizlazi iz gospodarskih, političkih, društvenih i ostalih ograničenja u zemljama Zapadnoga Balkana, a koje usporavaju njihov napredak te ostvarenje punopravnoga članstva u EU, a što predstavlja njihov ključni dugoročni strateški cilj. Stoga, ova skupina zemljama treba stvoriti uvjete za definiranje i implementaciju sveobuhvatnih strukturnih promjena, čime se će ostvariti konvergencija prema razvijenim zemljama članicama EU. Cilj istraživanje je znanstveno utemeljeno analizirati i prezentirati teorijske i zakonodavne temelje konvergencijskih procesa te provesti analizu dosadašnjega ostvarenja konvergencije u zemljama Zapadnoga Balkana.

Rad se sastoji od četiri međusobno povezana poglavlja. Nakon uvodnih razmatranja i definiranja ključnih elemenata istraživanja, u radu je objašnjena metodologija

\footnotetext{
BDP manji od $75 \%$ prosjeka EU

BDP na razini $75 \%-90 \%$ prosjeka EU

BDP veći od $90 \%$ prosjeka EU

Stupio na snagu 2009. godine.
} 
istraživanje te pružena sinteza ključnih teorijskih spoznaja, koje pobliže određuju proces konvergencije i njegove ključne elemente, s posebnim naglaskom na realnu konvergenciju. Sagledavanje teorijskih aspekata stvorilo je temelje za provedbu analize procesa realne konvergencije u zemljama Zapadnoga Balkana. Analiza je temeljena na dostupnim sekundarnim podatcima iz relevantnih međunarodnih baza podataka te je poslužila kao temelj za ocjenu ostvarenja realne konvergencije i identifikaciju ključnih problema i izazova ove skupine zemalja. Rad završava zaključnim razmatranjima, a koja sadrže ključne znanstvene spoznaje do kojih se došlo tijekom istraživanja.

\section{METODOLOGIJA ISTRAŽIVANJA}

$\mathrm{U}$ ovome radu je provedena deskriptivna analiza realne konvergencije u zemljama Zapadnoga Balkana. Analiza je temeljena na sekundarnim podatcima prikupljenima iz relevantnih europskih i međunarodnih baza podataka (Eurostat i Svjetska banka). Analizom je, uzimajući u obzir dostupnost podataka, obuhvaćeno razdoblje od 2008. - 2017. godine.

Uvažavajući teorijsku utemeljenost konvergencijskih procesa prezentiranu u nastavku rada, realna konvergencija je analizirana pomoću tri skupine indikatora: pokazatelji gospodarskoga rasta, pokazatelji tržišta rada i životnoga standarda te „razvojni indikatori“.

U skupini indikatora gospodarskoga rasta analizirane su razine BDP-a per capita (u američkim dolarima) te stope rasta BDP-a (\%), a što predstavlja uobičajeni način izražavanja gospodarskih kretanja u većini ekonomskih istraživanja.

Pozitivna kretanja indikatora gospodarskoga rasta su usko povezana sa kretanjima tržišta rada i poboljšanja životnog standarda, a što nalaže potrebu orijentacije na ovu skupinu indikatora. Stoga, skupina indikatora tržišta rada i životnoga standarda obuhvaća razine nezaposlenosti (\%), stope zaposlenosti stanovništva 30-34 godine, stanovništvo pri riziku od siromaštva i socijalne isključenosti, minimalne plaće (u eurima) te javna izdvajanja za zdravstvo (\% BDP-a), a što je u skladu sa metodologijom EU. Nadalje, suvremena kretanja i orijentacija EU stavlja sve veći naglasak na ubrzavanje gospodarskoga rasta te unaprjeđenje životnoga standarda temeljeno na suvremenim izvorima gospodarskoga rasta $\mathrm{tj}$. znanstveno-istraživačkim aktivnostima, obrazovanju te njihovim produktima, a što je posebno izraženo u strategiji EUROPA $2020^{6}$. Stoga, uvažavajući ključne prioritete i ciljeve ove Strategije, skupinom razvojnih indikatora obuhvaćena su ulaganja u istraživanje i razvoj (\% BDP-a), ulaganja u obrazovanje (\% BDP-a),

$6 \quad$ Strategija je definirana za razdoblje 2010. - 2020. godine. 
rano napuštanje školovanja (\%), udio stanovništva 30-34 godine sa završenim tercijarnim obrazovanjem te stopa rasta produktivnosti.

Analiza je obuhvatila šest zemalja Zapadnoga Balkana koje trenutačno imaju status kandidatkinja i službenih kandidatkinja za članstvo EU. S obzirom na složenost $\mathrm{u}$ definiranju pojma Zapadni Balkan, analiza je temeljena na stajalištu EU prema kojem Zapadni Balkan čini zemlje bivše Jugoslavije, s izuzetkom Slovenije i dodatkom Albanije (Milardović, 2000). Stoga, provedenom analizom su obuhvaćene ${ }^{7}$ Albanija, Bosna i Hercegovina, Crna Gora, Kosovo, Sjeverna Makedonija ${ }^{8}$ i Srbija.

Ograničenja istraživanja proizlaze iz relativne nedostupnosti određenih indikatora u pojedinim promatranim zemljama, što je djelomično utjecalo na sami tijek i provedu istraživanja. Naime, relevantne europske i međunarodne statističke baze još uvijek ne pružaju potpune i strukturirane vremenske nizove podataka za ovu skupinu zemalja. Slična situacija je prisutna i na nacionalnoj razini. Ovakva situacija uvelike ograničava dubinsko istraživanje makroekonomskih i povezanih trendova u ovoj skupini zemalja, a koja, u skladu sa prioritetnim određenjima EU, zauzima sve veću pažnju ekonomske znanosti.

\section{TEORIJSKA UTEMELJENOST KONVERGENCIJE}

Konvergencija predstavlja kompleksan te jedan od ključnih pojmova koji oduvijek zaokuplja pozornost ekonomskih teoretičara, pri čemu se razlikuju njihovi stavovi, elementi te načini definiranja. Stoga, u definiranju ovoga pojma još uvijek nije postignut konsenzus teoretičara te su prisutne razlike u njegovu pojmovnom određivanju.

Ideja konvergencije uvedena je dijelu Jamesa Burhnama iz 1962. godine pod naslovom Menadžerska revolucija, u kojoj se provodi analiza američkoga društva. Temelj konvergencijskih teorija predstavlja stajalište prema kojem industrijalizirane zemlje postaju sve sličnije usprkos različitim početnim pozicijama u gospodarskom, političkom, društvenom i socijalnom smislu (Moussis, 2007). Prema Bjorkstennu (2000) razvojne razlike između zemalja proizlaze iz različitih naslijeđenih stanja, fizičkih osobina prostora, načina provođenja određenih politika itd., a koje uzrokuju diferencirane učinke primjene zajedničkih ili sličnih politika te je nužno djelovati u smjeru njihova smanjenja, što bi trebalo rezultirati povećanjem učinkovitosti primijenjenih politika. Predmet konvergencije najčešće je realna ekonomija, mjerena pokazateljima gospodarskog rasta. Međutim,

\footnotetext{
7 Naravno, analizom nije obuhvaćena niti Republika Hrvatska koja je 1.7.2013. godine postala punopravna članica EU.

8 Do veljače 2019. godine naziv države je bio Republika Makedonija.
} 
konvergencija se može odnositi i na različite aspekte društva i gospodarstva kao npr. konvergenciju kamatnih stopa, obrazovnih sustava te konvergenciju informacijsko - komunikacijskih tehnologija. Također, u suvremenim uvjetima poslovanja, kao najvažniji čimbenik konvergencije je određen ljudski kapital.

Uvažavajući etimološko podrijetlo pojma u latinskom jeziku (convergere), a koje označava približavanje ili primicanje, Bogunović (2001) ističe kako konvergencija podrazumijeva mogućnost pokretanja rasta i razvoja u svrhu eliminiranja razvojnih razlika između zemalja i/ili regija, dok Varblane i Vahter (2005) posebnu pozornost pridaju sustizanju razvojnih razlika siromašnijih zemalja u odnosu na bogatije. Stavove ovih autora sublimiraju Kandžija i Cvečić (2010) prema kojima konvergencija predstavlja proces sustavnoga smanjivanja razvojnih razlika među regijama/zemljama u određenom vremenskom razdoblju, pri čemu je posebnu pozornost potrebno usmjeriti na vremensku dimenziju i uvjete koji određuju smjer i brzinu odvijanja cjelokupnoga procesa. U skladu s prethodno navedenim, Bogunović (2001) ističe kako se konvergencijom provjerava koji su uvjeti i koje vremensko razdoblje potrebni za ostvarenje transformacije u promatranim gospodarstvima. S aspekta integriranja na europskom području, Jacobsen et al. (2004) upućuju na važnost ostvarivanja stabilnosti konvergencijskih procesa u svrhu ostvarivanja ekonomskih, političkih, socijalnih i društvenih ciljeva i prioriteta.

Islam (2003) ističe sedam ključnih oblika konvergencije, i to: 1) konvergencija unutar gospodarstva i konvergencija među gospodarstvima, 2) konvergencija stope ekonomskoga rasta te konvergencija razine dohotka, 3) beta i sigma konvergencija, 4) apsolutna i uvjetna konvergencija, 5) globalna i lokalna konvergencija, 6) konvergencija čimbenika produktivnosti te 7) deterministička i stohastička konvergencija.

Bogunović (2001) ističe kako se konvergencija temelji na neoklasičnom modelu gospodarskoga rasta, pri čemu je potrebno razlikovati beta i sigma konvergenciju. Pritom, Bogunović i Vukoja (2008) navode kako beta konvergencija podrazumijeva brži rast siromašnijih regija u odnosu na bogate. Prema ovome konceptu, dugoročno stabilne stope gospodarskoga rasta uvelike ovise o stopama tehnološkoga napretka te razvoju ljudskoga kapitala i radne snage. S druge strane, situaciju u kojoj sve zemlje konvergiraju prema istim razvojnim razinama (iskazanim prvenstveno stopama gospodarskoga rasta te razinama BDP-a per capita) određuju kao apsolutnu beta konvergenciju.

Uzimajući u obzir Bogunović (2001), Bogunović i Vukoja (2008) te Kandžija i Cvečić (2010), koncept sigma konvergencija, a čiji preduvjet (nužan, ali ne i dovoljan) predstavlja postojanje beta konvergencije, moguće je definirati kao disperziju realnoga dohotka po stanovniku, a koja se tijekom vremena smanjuje. 
Prema Monfortu (2008) sigma konvergencija je prikladniji pokazatelj budući da ona održava stvarno stanje budući da konkretno opisuje distribuciju dohotka među promatranim jedinicama.

Pri razmatranju pojma konvergencija, potrebno je definirati apsolutnu, ekonomsku i strukturnu konvergenciju. Apsolutna konvergencija pronalazi svoje temelje u Solow-Swanovom modelu gospodarskoga rasta (Solow, 1956), prema kojem će zemlje sličnih karakteristika, s nižim početnim razinama gospodarskoga rasta imati u odnosu na dugoročnu poziciju više stope rasta, s obzirom na pretpostavke o opadajućim prinosima tj. zemlje koje su siromašnije kapitalom imaju više stope povrata. Slične temeljne postavke su prisutne kod Bilas (2005), koja ekonomsku konvergenciju određuje kao proces približavanja vrijednosti ekonomskih pokazatelja, sa svrhom sustizanja razvojnih razina u bogatijim zemljama. Naravno, i u ovom slučaju je pozornost posvećena višim stopama rasta u siromašnijim zemljama.

Ostvarenje strukturne konvergencije je uvelike uvjetovano postojanjem sedam pretpostavki optimalnoga valutnog područja ${ }^{9}$, a u koje spadaju (Vujčić, 2003, Bilas, 2005) mobilnost faktora proizvodnje (rada), sličnost stopa inflacije, fleksibilnost cijena i nadnica, trgovinska otvorenost i prekogranična trgovina, kamatne stope, fiskalna integracija te usklađenost poslovnih ciklusa. Ipak, Krugman (1993) sagledavajući povezanost strukturne konvergencije i uspješnosti pojedine ekonomske integracije, kritički pristupa ovom procesu te navodi kako će integracijski procesi (prvenstveno zbog različitih veličina gospodarstava, eksternalija, sinergijskih učinaka itd.) zasigurno dovesti do povećane specijalizacije, divergencije u ekonomskim strukturama, asimetričnoga razvoja te, što je najvažnije, povećanja razvojnih razlika. S druge strane, Marelli i Signorelli (2010) navode kako će postizanje strukturne konvergencije, putem učinaka jedinstvenoga (u slučaju EU Unutarnjega tržišta) rezultirati pozitivnim učincima u vidu povećanja sličnosti gospodarskih sustava, a do koje će doći zbog djelovanja tržišnih instrumenata kao npr. politika konkurencije, liberalizacije tržišta kapitala, ostvarenja ostalih tržišnih sloboda itd. Također, autori navode kako će strukturna konvergencija zasigurno utjecati na ostvarenje realne konvergencije, a koja će se analizirati u nastavku istraživanja.

Najrašireniji i općeprihvaćeni način podjele ekonomske konvergencije podrazumijeva razmatranje realne i nominalne konvergencije. Realna konvergencija proizlazi iz prethodno definirane teorije optimalnih valutnih područja te ju je prema Jovančević (2005) moguće definirati kao rezultat jačanja ekonomske integracije

9 Prema Mundellu (1997) teorija optimalnih valutnih područja iskazuje koristi/troškove uvođenja zajedničke valute u određeno gospodarstvo. Autor ističe kako će zemlje težiti fiksiranju svojih tečaja ovisno o mobilnosti proizvodnih čimbenika te otvorenosti gospodarstva. 
između bogatijih i siromašnijih zemalja, a koja rezultira približavanjem razina produktivnosti i razina cijena među promatranim zemljama. U ovom slučaju je velika važnost stavljena na vremensku dimenziju. Naime, Kersan - Škabić i Mihaljević (2010) upozoravaju kako svaki pokušaj zemalja da čim prije dosegnu određene razvojne razine, bez kvalitetnog i osmišljenoga procesa dinamičkog upravljanja strukturnim promjenama, mogu rezultirati stagnacijom i ,nazadovanjem" gospodarstva te usporavanjem konvergencijskih procesa. Uz prethodno navedene pokazatelje autori (Kowalski 2003, Kulhanek, 2012) ističu i nužnost smanjivanja razlika u BDP-u per capita te ravnotežu realnog deviznog tečaja u procesu ostvarivanja realne konvergencije. Dratischova (2012) kao najvažnije pokazatelje realne konvergencije navodi razine BDP-a per capita, stopu rasta BDP-a te razine zaposlenosti i nezaposlenosti. Kandžija i Cvečić (2010) te Tomljanović (2017) posebnu pažnju usmjeravaju na kvalitetu i razvoj ljudskih resursa, čime upozoravaju na nužnost orijentacije manje razvijenih zemalja prema suvremenim pokretačima gospodarskoga rasta, prvenstveno kroz ulaganje $\mathrm{u}$ istraživanje i razvoj te unaprjeđenje obrazovanja. Ovakav pristup autora, uz uvažavanje stavova prethodnika, predstavlja temelj istraživanja konvergencijskih procesa u zemljama Zapadnoga Balkana, obilježenih različitim političkim, ekonomskim i društvenim problemima i izazovima. Prema Lavraču i Žumeru (2003) slabije razvijene zemlje, a među koje svakako ulaze i zemlje Zapadnoga Balkana moraju osigurati uvjete za implementaciju sveobuhvatnih i kvalitetnih strukturnih reformi te postići okončanje započetoga procesa tranzicije.

Dratishova (2012) predlaže tri načina definiranja realne konvergencije, a koji uporište nalaze u prethodno prezentiranim stavovima ekonomskih teoretičara. Prema prvom načinu, konvergencija podrazumijeva približavanje razina BDP-a per capita dinamičkoj ravnotež $i^{10}$. Prema drugoj definiciji, konvergencija podrazumijeva sinkronizaciju poslovnih ciklusa te njihovo usklađivanje sa pretpostavkama teorije optimalnih valutnih područja. Treća definicija navodi kako se konvergencija na razini EU shvaća i kao kohezija. Autor ovoga rada je sklon treći pristup sagledavati sa određenom dozom opreza. Naime, uvažavajući stavove Kandžija $(2003,2008)$ te Kandžija i Cvečić (2010) potrebno je istaknuti kako je konvergencija proces, dok kohezija predstavlja cilj, koji se želi postići kroz dinamičko upravljanje strukturnim promjenama.

Nominalna konvergencija je uvedena Ugovorom o EU (Ugovor iz Maastrichta) iz 1992. godine te određuje uvjete koje zemlje moraju zadovoljiti ukoliko žele uvesti zajedničku valutu euro. Svrha ove skupine kriterija je osigurati monetarnu i makroekonomsku stabilnost u eurozoni, u cilju ostvarivanja dugoročnoga gospodarskog rasta (Ott, 2004). Kriteriji nominalne konvergencije podrazumijevaju ostvarenje inflacijskoga i kamatnoga kriterija, kriterija stabilnosti javnih financija te kamatnoga kriterija (Kesner-Škreb, 2006). Prema inflacijskom kriteriju

10 U ovom slučaju dinamička ravnoteža podrazumijeva dugoročnu ravnotežu sa stabilnim dohotkom per capita ili povećanjem stope tehnološkoga napretka. 
stopa inflacije određene zemlje članice ne smije biti veća više od 1,5 postotnih poena prosječne stope inflacije za tri zemlje EU s najnižom inflacijom u godini koja prethodi preispitivanju stanja u zemlji članici kandidatkinji za EMU. Kriterij javnih financija uzima u obzir deficit proračuna opće države te razinu javnoga duga. Pritom, udio proračunskog deficita opće države u BDP-u ne smije prelaziti $3 \%$ na kraju prethodne financijske godine. Ukoliko nije tako, dopušta se da deficit privremeno bude iznad (ali još uvijek blizu) razine od 3\%. Što se tiče javnoga duga, njegova razina (udio u BDP-u) ne smije biti iznad 60\% na kraju prethodne financijske godine. Ukoliko nije tako, udio mora pokazivati tendenciju značajnog smanjivanja i mora se zadovoljavajućom dinamikom približavati referentnoj vrijednosti. Isto tako, nominalna dugoročna kamatna stopa (na državne obveznice ili slične vrijednosnice) u praksi ne smije za više od dva postotna poena prijeći odgovarajuću kamatnu stopu u (najviše) tri zemlje članice s najnižom inflacijom. Kriterij stabilnosti deviznoga tečaja zahtijeva dvogodišnje sudjelovanje u europskom tečajnom mehanizmu (ERM II).

Procesi realne i nominalne konvergencije mogu se nadopunjavati ili biti u sukobu. U slučaju podupirućega djelovanja, ostvarenje realne konvergencije putem strukturnih fondova, a koji predstavljaju najvažniji instrument europske regionalne politike, rezultirati će povećanjem potražnje putem veće fleksibilnosti roba i tržišta rada, a što će imati izravan utjecaj na nominalnu konvergenciju. S druge strane, ostvarivanjem nominalne konvergencije stabiliziranjem inflacijskih očekivanja moguće je poboljšati uvjete za ostvarivanje gospodarskoga rasta (Detken et al., 2004). Također, autori analiziraju sedam ključnih scenarija u kojima može doći do konflikta realne i nominalne konvergencije: 1) više stope inflacije su vezane uz više stope gospodarskog rasta, 2) konvergencijska očekivanja u području cijena mogu dovesti do smanjenja dugoročnih kamatnih stopa, što će potencijalno rezultirati višim nominalnim kamatnim stopama u budućnosti, 3) nemogućnost istodobnog ostvarenja inflacijskog i tečajnog kriterija, 4) ostvarenje tečajnog kriterija može rezultirati neodrživom ravnotežom platne bilance ukoliko se tečaj fiksira na neprikladnoj razini, 5) povećanje produktivnosti može izazvati inflaciju, 6) gospodarski rast, priljev kapitala te jačanje financijske integriranosti mogu usporiti konvergenciju kamatnih stopa te 7) povećanje priljeva kapitala i otvorenosti gospodarstva može uzrokovati volatilnost nominalnog deviznog tečaja.

Od ostalih relevantnih pokazatelja realne konvergencije potrebno je izdvojiti Deka europski konvergencijski indikator, koji u obzir uzima monetarnu, fiskalnu, realnu i institucionalnu konvergenciju. Pritom, fiskalna konvergencija obuhvaća udio proračunskog deficita u BDP-u, udio privatne potrošnje u BDP-u, udio javnog duga u BDP-u te udio vanjskog duga u BDP-u. Monetarna konvergencija obuhvaća stope inflacije, kamatne stope, devizni tečaj te stope rasta kredita. U području realne konvergencije kao ključni pokazatelji se uzimaju razine BDP-a 
per capita, udio primarnog sektora u BDP-u, stopa nezaposlenosti te udio trgovine s EU u ukupnoj trgovini. Također, institucionalna konvergencija obuhvaća uspješnost politike, bankarske institucije, uspostavu pravne države te dostignutu razinu u integracijskom procesu prema EU (Dekabank, 2019).

$\mathrm{Na}$ temelju prethodno prezentiranih teorijskih pristupa konvergencijskim procesima, moguće je zaključiti kako konvergencija predstavlja složen i sveobuhvatan proces, čiji je temeljni cilj smanjivanje i ujednačavanje razvojnih razlika između regija, s krajnjim ciljem ostvarenja gospodarskoga rasta, povećanja produktivnosti te poboljšanja životnoga standarda. Suvremena ekonomska kretanja te izazovi europskih integracijskih procesa u slučaju zemalja Zapadnoga Balkana stavljaju nove izazove, osobito u kontekstu implementacije novih razvojnih paradigmi temeljenih na suvremenim izvorima gospodarskoga rasta, u svrhu ubrzanja integracijskih procesa te ostvarenja konvergencije i kohezije.

\section{ANALIZA REALNE KONVERGENCIJE U ZEMLJAMA ZAPADNOGA BALKANA}

Podatci iz Tablice 1. upućuju kako su sve zemlje Zapadnoga Balkana u promatranom razdoblju ostvarile povećanje BDP-a per capita. Prema posljednje dostupnim podatcima, najvišu razinu BDP-a per capita imaju Crna Gora $(8760,69$ američkih dolara) i Srbija (7234 američkih dolara), dok je najniža razina prisutna na Kosovu (5951,32 američkih dolara). Ipak, u usporedbi sa prosjekom EU, još uvijek su prisutna prilična zaostajanja. Naime, prosjek EU u 2018. godini je iznosio 36531,73 američkih dolara, što je gotovo 6 puta više od prosjeka $(6066,131$ američkih dolara) u zemljama Zapadnoga Balkana.

Tablica 1. Kretanje BDP-a per capita u zemljama Zapadnoga Balkana i EU u razdoblju 2008.-2018. godine (u američkim dolarima)

\begin{tabular}{|c|c|c|c|c|c|c|c|}
\hline $\begin{array}{c}\text { Godina/ } \\
\text { Zemlja }\end{array}$ & Albanija & $\begin{array}{c}\text { Bosna i } \\
\text { Hercegovina }\end{array}$ & $\begin{array}{c}\text { Crna } \\
\text { Gora }\end{array}$ & Kosovo & $\begin{array}{c}\text { Sjeverna } \\
\text { Makedonija }\end{array}$ & Srbija & EU \\
\hline 2008. & 4370,54 & 5090,93 & 7367,75 & 3254,82 & 4793,44 & 7101,04 & 38198,60 \\
\hline 2009. & 4114,13 & 4714,70 & 6727,11 & 3209,69 & 4544,01 & 6169,11 & 34035,82 \\
\hline 2010. & 4094,36 & 4635,52 & 6682,28 & 3283,51 & 4542,90 & 5735,42 & 33729,21 \\
\hline 2011. & 4437,18 & 5092,55 & 7318,74 & 3736,36 & 5063,79 & 6809,16 & 36457,41 \\
\hline 2012. & 4247,61 & 4778,64 & 6586,72 & 3600,67 & 4698,14 & 6015,95 & 34284,54 \\
\hline 2013. & 4413,08 & 5131,39 & 7186,43 & 3876,96 & 5210,68 & 6755,07 & 35635,91 \\
\hline 2014. & 4578,67 & 5329,64 & 7378,35 & 4054,72 & 5468,48 & 6600,06 & 36736,57 \\
\hline 2015. & 3952,83 & 4727,28 & 6514,27 & 3574,54 & 4840,27 & 5585,12 & 32265,08 \\
\hline 2016. & 4124,11 & 4994,68 & 7028,94 & 3697,12 & 5129,16 & 5756,38 & 32379,65 \\
\hline 2017. & 4532,89 & 5394,59 & 7784,07 & 3948,09 & 5417,64 & 6284,19 & 33864,17 \\
\hline 2018. & 5253,63 & 5951,32 & 8760,69 & 4281,29 & 6083,72 & 7234,00 & 36531,73 \\
\hline
\end{tabular}

Izvor: Izrada autora na temelju Svjetska banka (1), 2019 
Nadalje, u promatranom razdoblju zemlje Zapadnoga Balkana su rasle prosječnom stopom od 3,83\% godišnje, a što predstavlja brži rast od EU prosjeka (2\%). Pritom, najveće prosječne stope gospodarskoga rasta ostvaruju Kosovo, Albanija i Sjeverna Makedonija, dok je gospodarski rast najmanji u Bosni i

Hercegovini (Tablica 2.). Ovakva situacija je u skladu sa temeljnim postavkama konvergencijskih teorija, koje upućuju na brži rast u manje razvijenim zemljama.

Tablica 2. Stope rasta BDP-a u zemljama Zapadnoga Balkana i EU u razdoblju 2008.2018. godine $(\%)$

\begin{tabular}{|c|c|c|c|c|c|c|c|}
\hline $\begin{array}{c}\text { Godina/ } \\
\text { Zemlja }\end{array}$ & Albanija & $\begin{array}{c}\text { Bosna i } \\
\text { Hercegovina }\end{array}$ & $\begin{array}{c}\text { Crna } \\
\text { Gora }\end{array}$ & Kosovo & $\begin{array}{c}\text { Sjeverna } \\
\text { Makedonija }\end{array}$ & Srbija & EU \\
\hline 2008. & 7,50 & 5,43 & 7,22 & 2,64 & 5,47 & 5,66 & 0,54 \\
\hline 2009. & 3,35 & $-3,00$ & $-5,80$ & 3,34 & $-0,36$ & $-2,73$ & $-4,34$ \\
\hline 2010. & 3,71 & 0,87 & 2,73 & 3,31 & 3,36 & 0,73 & 2,09 \\
\hline 2011. & 2,55 & 0,96 & 3,23 & 4,81 & 2,34 & 2,04 & 1,76 \\
\hline 2012. & 1,42 & $-0,82$ & $-2,72$ & 2,90 & $-0,46$ & $-0,68$ & $-0,40$ \\
\hline 2013. & 1,00 & 2,35 & 3,55 & 3,43 & 2,92 & 2,89 & 0,26 \\
\hline 2014. & 1,77 & 1,15 & 1,78 & 1,20 & 3,63 & $-1,59$ & 1,78 \\
\hline 2015. & 2,23 & 3,09 & 3,39 & 4,09 & 3,86 & 1,78 & 2,35 \\
\hline 2016. & 3,35 & 3,15 & 2,95 & 4,06 & 2,85 & 3,34 & 2,03 \\
\hline 2017. & 3,84 & 3,16 & 4,72 & 4,23 & 0,24 & 2,05 & 2,48 \\
\hline 2018. & 4,00 & 3,07 & 4,85 & 4,15 & 2,66 & 4,30 & 2,00 \\
\hline
\end{tabular}

Izvor: Izrada autora na temelju Svjetska banka (2), 2019

Prethodno prezentirani podatci upućuju na ostvarivanje gospodarskoga rasta i napretka u promatranim zemljama. Međutim, podatci o tržištu rada koji će biti prezentirani u nastavku rada upućuju na mnogobrojne probleme i ograničenja ovih zemalja u procesu uključivanja u EU i ostvarivanja konvergencije.

Podatci iz Tablice 3. upućuju kako se promatrane zemlje, iako je ostvaren određeni napredak u usporedbi sa početkom razdoblja, još uvijek suočavaju sa veoma visokim stopama nezaposlenosti. Prema ovome pokazatelju, ,vodeće mjesto“ zauzimaju Kosovo (30,3\%) i Sjeverna Makedonija (22,4\%), dok je situacija „,najpovoljnija“ u Srbiji (13,6\%) i Albaniji (13,7\%). Prosječna stopa nezaposlenosti u promatranim zemljama iznosi $26,9 \%$, što je gotovo četiri puta više od EU prosjeka. 
Tablica 3. Ukupna stopa nezaposlenosti u zemljama Zapadnoga Balkana i EU u razdoblju 2008.-2017. godine (\%)

\begin{tabular}{|c|c|c|c|c|c|c|c|}
\hline $\begin{array}{c}\text { Godina/ } \\
\text { Zemlja }\end{array}$ & Albanija & $\begin{array}{c}\text { Bosna i } \\
\text { Hercegovina }\end{array}$ & $\begin{array}{c}\text { Crna } \\
\text { Gora }\end{array}$ & Kosovo & $\begin{array}{c}\text { Sjeverna } \\
\text { Makedonija }\end{array}$ & Srbija & EU \\
\hline 2008. & 13,0 & 23,5 & 16,8 & 47,5 & 33,8 & 13,8 & 7 \\
\hline 2009. & 13,8 & 24,1 & 19,1 & 45,4 & 32,2 & 16,3 & 9 \\
\hline 2010. & 14,0 & 27,3 & 19,7 & - & 32,0 & 19,4 & 9,6 \\
\hline 2011. & 14,0 & 27,6 & 19,7 & - & 31,4 & 23,1 & 9,7 \\
\hline 2012. & 13,4 & 28,2 & 19,7 & 30,9 & 31,0 & 24,1 & 10,5 \\
\hline 2013. & 15,9 & 27,6 & 19,5 & 30,0 & 29,0 & 22,3 & 10,9 \\
\hline 2014. & 17,5 & 27,6 & 18,0 & 35,3 & 28,0 & 19,4 & 10,2 \\
\hline 2015. & 17,1 & 27,9 & 17,5 & 32,9 & 26,1 & 17,8 & 9,4 \\
\hline 2016. & 15,2 & 25,5 & 17,8 & 27,5 & 23,7 & 15,4 & 8,6 \\
\hline 2017. & 13,7 & 20,7 & 16,1 & 30,3 & 22,4 & 13,6 & 7,6 \\
\hline
\end{tabular}

Izvor: Izrada autora na temelju Eurostat (1) i Eurostat (5), 2019

Nadalje, važan indikator predstavlja i udio zaposlenoga stanovništva od 20-64 godine (Tablica 4). Najviše stope zaposlenosti u zemljama Zapadnoga Balkana ostvaruju Albanija (63,9\%), Srbija $(63,1 \%)$ te Crna Gora $(58,2 \%)$, dok je ona najniža na Kosovu $(34,4)$. Prosječna razina zaposlenosti stanovništva 20-64 godine u ovim zemljama iznosi $63,88 \%$, čime se one nalaze značajno ispod EU prosjeka. Imajući na umu cilj EU proklamiran strategijom Europa 2020, a koji ističe potrebu ostvarivanja prosječne zaposlenosti stanovništva 20-64 godine od $75 \%$ do 2020. godine (Europska komisija, 2019), vidljivo je kako promatrane zemlje moraju definirati i implementirati sveobuhvatne reforme tržišta rada, u cilju ostvarivanja napretka i konvergencije.

Tablica 4. Kretanje stope zaposlenosti u zemljama Zapadnoga Balkana i EU u razdoblju 2008.-2017. godine (\% stanovništva 20-64 godine)

\begin{tabular}{|c|c|c|c|c|c|c|c|}
\hline $\begin{array}{c}\text { Godina/ } \\
\text { Zemlja }\end{array}$ & Albanija & $\begin{array}{c}\text { Bosna i } \\
\text { Hercegovina }\end{array}$ & $\begin{array}{c}\text { Crna } \\
\text { Gora }\end{array}$ & Kosovo & $\begin{array}{c}\text { Sjeverna } \\
\text { Makedonija }\end{array}$ & Srbija & EU \\
\hline 2008. & 60,8 & 44,8 & 56,1 & - & 46,3 & 58,2 & 70,2 \\
\hline 2009. & 60,4 & 44,2 & 54,0 & - & 47,9 & 54,7 & 68,9 \\
\hline 2010. & 60,3 & 42,8 & 52,9 & - & 48,1 & 51,4 & 68,5 \\
\hline 2011. & 64,9 & 42,5 & 50,9 & - & 48,4 & 49,3 & 68,6 \\
\hline 2012. & 62,4 & 42,5 & 50,9 & 29,7 & 48,2 & 49,0 & 68,4 \\
\hline 2013. & 56,7 & 42,8 & 52,6 & 33,0 & 50,3 & 51,3 & 68,4 \\
\hline 2014. & 56,6 & 43,2 & 55,6 & 31,3 & 51,3 & 54,8 & 69,2 \\
\hline 2015. & 59,3 & 43,2 & 52,4 & 29,1 & 51,9 & 56,0 & 70,1 \\
\hline 2016. & 62,1 & 44,2 & 52,2 & 32,3 & 53,3 & 59,1 & 71,1 \\
\hline 2017. & 63,9 & 46,6 & 58,2 & 34,4 & 54,8 & 61,5 & 72,2 \\
\hline
\end{tabular}

Izvor: Izrada autora na temelju Eurostat (1) i Eurostat (6), 2019 
Uz utvrđenu nepovoljnu situaciju na tržištu rada, stanovništvo ovih zemalja je suočeno i sa niskim razinama minimalnih plaća (Tablica 5.). Ovakva situacija rezultira nepovoljnim društvenim i socijalnim fenomenima, koji se ponajprije manifestiraju kroz sveopće nezadovoljstvo svim segmentima društva te povećanim iseljavanjima, ponajprije mladoga i obrazovanoga stanovništva te povećanjem razine stanovništva pri riziku od siromaštva i socijalne isključenosti.

Dostupni podatci o minimalnim plaćama upućuju na njihovo povećanje u promatranom razdoblju te je vidljivo kako je njihova razina najviša u Crnoj Gori (288,05 eura), Sjevernoj Makedoniji (236,05 eura) te Srbiji (253,10 eura). Ukoliko se ovi podatci usporedbe sa zemljama članicama EU usporedivih značajki, vidljivo je kako analizirane zemlje ostvaruju razinu minimalnih plaća, koja je veća od razina u Bugarskoj (184,07 eura) te Rumunjskoj (217,5 eura) (Eurostat (7), 2019).

Tablica 5. Minimalne plaće u zemljama Zapadnoga Balkana u razdoblju 2008.-2017. godine (u eurima)

\begin{tabular}{|c|c|c|c|c|c|c|}
\hline $\begin{array}{c}\text { Godina/ } \\
\text { Zemlja }\end{array}$ & Albanija & $\begin{array}{c}\text { Bosna i } \\
\text { Hercegovina }\end{array}$ & Crna Gora & Kosovo & $\begin{array}{c}\text { Sjeverna } \\
\text { Makedonija }\end{array}$ & Srbija \\
\hline 2008. & 139,29 & - & - & - & - & 233,09 \\
\hline 2009. & 137,66 & - & - & - & - & 220,23 \\
\hline 2010. & 139,25 & - & - & - & - & 203,29 \\
\hline 2011. & 141,43 & - & - & - & - & 234,88 \\
\hline 2012. & 151,99 & - & - & - & - & 234,90 \\
\hline 2013. & 156,07 & - & 288,05 & - & 198,95 & 236,27 \\
\hline 2014. & 156,85 & - & 288,05 & - & 213,02 & 232,68 \\
\hline 2015. & 157,60 & - & 288,05 & - & 227,04 & 236,40 \\
\hline 2016. & 160,20 & - & 288,05 & - & 236,05 & 230,14 \\
\hline 2017. & 181,01 & - & 288,05 & - & 277,62 & 253,10 \\
\hline
\end{tabular}

Izvor: Izrada autora na temelju Eurostat (2), 2019.

Kao što je prethodno navedeno, nepovoljna situacija na tržištu rada te niske razine minimalnih plaća rezultiraju povećanjem udjela stanovništva koje se nalazi pri riziku od siromaštva i socijalne isključenosti. U promatranim zemljama najviša razina stanovništva pri riziku od siromaštva i socijalne isključenosti je prisutna u Srbiji (31,6\%), Crnoj Gori (31,5\%) te Sjevernoj Makedoniji (25,9\%) (Eurostat (4), 2019). Ovakve razine (osim u Sjevernoj Makedoniji) se nalaze osjetno iznad EU prosjeka, koji se u 2017. godini iznosio 22,4\% (Eurostat (8), 2019).

Pri razmatranju indikatora životnoga standarda, potrebno je uzeti u obzir i izdvajanja za zdravstvo (Tablica 6). Dostupni podatci ukazuju kako su najveće razine ostvarene u Bosni i Hercegovini (9,23\% BDP-a) i Srbiji (9,14\% BDP-a), čime se one nalaze neznatno ispod prosjeka EU (9,93\% BDP-a). Ostale zemlje Zapadnoga Balkana nalaze se na osjetno nižim razinama. 
Tablica 6. Izdvajanja za zdravstvo u zemljama Zapadnoga Balkana i EU u razdoblju 2008.-2016. godine (\% BDP-a)

\begin{tabular}{|c|c|c|c|c|c|c|c|}
\hline $\begin{array}{c}\text { Godina/ } \\
\text { Zemlja }\end{array}$ & Albanija & $\begin{array}{c}\text { Bosna i } \\
\text { Hercegovina }\end{array}$ & $\begin{array}{c}\text { Crna } \\
\text { Gora }\end{array}$ & Kosovo & $\begin{array}{c}\text { Sjeverna } \\
\text { Makedonija }\end{array}$ & Srbija & EU \\
\hline 2008. & 5,57 & 9,69 & - & - & 6,58 & 10,06 & 8,95 \\
\hline 2009. & 5,09 & 9,02 & - & - & 6,54 & 9,91 & 9,73 \\
\hline 2010. & 5,01 & 9,02 & - & - & 6,72 & 10,10 & 9,65 \\
\hline 2011. & 5,60 & 9,18 & - & - & 6,52 & 9,66 & 9,62 \\
\hline 2012. & 5,85 & 9,49 & - & - & 6,61 & 9,92 & 9,68 \\
\hline 2013. & 6,34 & 9,49 & - & - & 6,72 & 9,90 & 9,97 \\
\hline 2014. & 6,92 & 9,56 & - & - & 6,29 & 9,84 & 9,98 \\
\hline 2015. & 6,82 & 9,35 & - & - & 6,35 & 9,41 & 9,93 \\
\hline 2016. & 6,70 & 9,23 & 7,64 & - & 6,34 & 9,14 & 9,93 \\
\hline
\end{tabular}

Izvor: Izrada autora na temelju Svjetska banka (3), 2019.

Provedenom analizom indikatora gospodarskoga rasta te tržišta rada i životnoga standarda utvrđena su određena pozitivna kretanja. Ipak, usporedbom sa razvojnim razinama u EU, a što predstavlja ključni strateški cilj ove skupine zemalja, utvrđeno je kako su još uvijek prisutne osjetne razvojne razlike. Promatrana skupina zemalja se nalazi pred izazovom prevladavanja identificiranih ograničenja. Takva situacija nalaže orijentaciju na skupinu tzv. razvojnih indikatora, a što je u fokus stavljeno i u ključnim europskim politikama i strategijama.

Dostupni podatci iz Tablice 7. ukazuju na povećanje razine ulaganja u istraživanje i razvoj u promatranom razdoblju. Ipak, ovi se indikatori u promatranim zemljama još uvijek nalaze na značajno niskim razinama (osobito u Bosni i Hercegovini). Izuzetak predstavlja Srbija, koja sa 0,93\% BDP-a ulaganja u istraživanje i razvoj ostvaruje najvišu razinu, koja je međutim osjetno ispod prosjeka EU $(2,03 \%$ BDP-a).

Tablica 7. Ulaganja u istraživanje i razvoj u zemljama Zapadnoga Balkana i EU u razdoblju 2008.-2017. godine (\% BDP-a)

\begin{tabular}{|c|c|c|c|c|c|c|c|}
\hline $\begin{array}{c}\text { Godina/ } \\
\text { Zemlja }\end{array}$ & Albanija & $\begin{array}{c}\text { Bosna i } \\
\text { Hercegovina }\end{array}$ & $\begin{array}{c}\text { Crna } \\
\text { Gora }\end{array}$ & Kosovo & $\begin{array}{c}\text { Sjeverna } \\
\text { Makedonija }\end{array}$ & Srbija & EU \\
\hline 2008. & - & 0,02 & - & - & 0,22 & 0,71 & 1,84 \\
\hline 2009. & - & 0,02 & - & - & 0,20 & 0,87 & 1,93 \\
\hline 2010. & - & - & - & - & 0,22 & 0,74 & 1,93 \\
\hline 2011. & - & - & 0,31 & - & 0,22 & 0,72 & 1,97 \\
\hline 2012. & - & 0,27 & - & - & 0,33 & 0,91 & 2,01 \\
\hline 2013. & - & 0,32 & 0,37 & - & 0,44 & 0,73 & 2,02 \\
\hline 2014. & - & 0,26 & 0,36 & - & 0,52 & 0,77 & 2,04 \\
\hline
\end{tabular}




\begin{tabular}{|l|l|l|c|c|c|c|c|}
\hline 2015. & - & 0,22 & 0,37 & - & 0,44 & 0,87 & 2,04 \\
\hline 2016. & - & 0,22 & - & - & 0,43 & 0,89 & 2,03 \\
\hline 2017. & - & 0,20 & - & - & 0,35 & 0,93 & 2,03 \\
\hline
\end{tabular}

Izvor: Izrada autora na temelju Svjetska banka (4), 2019.

Ulaganja u istraživanje i razvoj bi trebala biti praćena i odgovarajućim razinama ulaganja u obrazovanje. Naime, relevantni ekonomski teoretičari ističu upravo kvalitetu ljudskih potencijala kao jedan od ključnih preduvjeta ostvarivanja konvergencije.

Dostupni podatci iz Tablice 8. upućuju na relativno visoke vrijednosti ovoga pokazatelja u promatranim zemljama, pri čemu Kosovo ostvaruje najviše razine. Ovakvim vrijednostima promatrane zemlje ostvaruju razine koje se nalaze osjetno iznad EU prosjeka (2,3\% BDP-a u 2017. godini) (Eurostat (11), 2019). Međutim, sama veličina ulaganja nije dovoljna za ostvarenje napretka i smanjivanja razvojnih razlika. Naime, ona bi trebala biti usmjerena u konkretne ciljeve i prioritete, čija će se realizacija manifestirati kroz pozitivne ekonomske i socijalne učinke.

Tablica 8. Ulaganja u obrazovanje u zemljama Zapadnoga Balkana u razdoblju 2008.2017. godine (\% BDP-a)

\begin{tabular}{|c|c|c|c|c|c|c|}
\hline Godina/Zemlja & Albanija & $\begin{array}{c}\text { Bosna i } \\
\text { Hercegovina }\end{array}$ & $\begin{array}{c}\text { Crna } \\
\text { Gora }\end{array}$ & Kosovo & $\begin{array}{c}\text { Sjeverna Ma- } \\
\text { kedonija }\end{array}$ & Srbija \\
\hline 2008. & 3,5 & - & - & - & - & 4,4 \\
\hline 2009. & 3,3 & - & - & - & - & 4,5 \\
\hline 2010. & 3,4 & - & - & - & - & 4,3 \\
\hline 2011. & 3,2 & - & - & - & - & 4,2 \\
\hline 2012. & 3,3 & - & - & 3,9 & - & 4,3 \\
\hline 2013. & 3,3 & - & - & 3,8 & - & 4,1 \\
\hline 2014. & 3,3 & - & - & 3,7 & - & 4,0 \\
\hline 2015. & 3,1 & - & - & 4,5 & - & 3,7 \\
\hline 2016. & 3,1 & - & - & 4,6 & - & 3,6 \\
\hline 2017. & 3,1 & - & - & 4,4 & - & 3,7 \\
\hline
\end{tabular}

Izvor: Izrada autora na temelju Eurostat (3), 2019.

Kao jedna od posljedica nepovoljne gospodarske i socijalne situacije, često se javlja i trend ranoga napuštanja školovanja. Podatci iz Tablice 9. ukazuju kako u promatranoj skupini zemalja najviše razine ranoga napuštanja školovanja ostvaruju Albanija (19,6\%) te Kosovo (12,2\%). Ostale zemlje (osim Sjeverne Makedonije) se nalaze na osjetno nižim razinama (ispod 6,2\%), što svakako predstavlja pozitivan trend. Također, većina promatranih zemalja se nalazi ispod prosjeka EU (10,6\% u 2017. godini) (Eurostat (9), 2019). 
Tablica 9. Rano napuštanje školovanja ${ }^{11}$ u zemljama Zapadnoga Balkana u razdoblju 2008.-2017. godine (\%)

\begin{tabular}{|c|c|c|c|c|c|c|}
\hline $\begin{array}{c}\text { Godina/ } \\
\text { Zemlja }\end{array}$ & Albanija & $\begin{array}{c}\text { Bosna i } \\
\text { Hercegovina }\end{array}$ & Crna Gora & Kosovo & $\begin{array}{c}\text { Sjeverna } \\
\text { Makedonija }\end{array}$ & Srbija \\
\hline 2008. & 39,0 & 9,0 & 8,6 & - & 19,6 & 11,7 \\
\hline 2009. & 35,5 & 7,4 & 7,0 & - & 16,2 & 9,3 \\
\hline 2010. & 31,9 & 7,9 & 6,6 & - & 15,5 & 8,2 \\
\hline 2011. & 35,2 & 8,0 & 6,7 & - & 13,5 & 8,5 \\
\hline 2012. & 31,6 & 7,9 & 6,6 & 18,4 & 11,7 & 8,1 \\
\hline 2013. & 30,6 & 6,7 & 5,8 & 18,4 & 11,4 & 8,9 \\
\hline 2014. & 26,0 & 5,8 & 5,1 & 16,5 & 12,5 & 8,5 \\
\hline 2015. & 21,3 & 5,2 & 5,7 & 14,5 & 11,3 & 7,5 \\
\hline 2016. & 19,6 & 4,9 & 5,5 & 12,7 & 9,9 & 7,0 \\
\hline 2017. & 19,6 & 5,1 & 5,4 & 12,2 & 8,5 & 6,2 \\
\hline
\end{tabular}

Izvor: Izrada autora na temelju Eurostat (3), 2019.

Pozitivni trendovi u području obrazovanja vidljivi su i kod pokazatelja stanovništva sa završenim tercijarnim obrazovanjem, a koji bilježi povećanje u promatranom razdoblju. Pritom, najveće vrijednosti ostvaruju Crna Gora (34\%), Srbija $(31,4 \%)$ te Sjeverna Makedonija (30,6\%) (Tablica 10). Ipak, iako je ostvaren određeni napredak, i kod ovoga indikatora su prisutna značajna zaostajanja za prosjekom EU (40,7\%) (Eurostat (10), 2019), a što predstavlja i jedan od definiranih ciljeva strategije EUROPA 2020.

Tablica 10. Stanovništvo (30-34 godine) sa završenim tercijarnim obrazovanjem u zemljama Zapadnoga Balkana u razdoblju 2008.-2017. godine (\%)

\begin{tabular}{|c|c|c|c|c|c|c|}
\hline $\begin{array}{c}\text { Godina/ } \\
\text { Zemlja }\end{array}$ & Albanija & $\begin{array}{c}\text { Bosna i } \\
\text { Hercegovina }\end{array}$ & Crna Gora & Kosovo & $\begin{array}{c}\text { Sjeverna Make- } \\
\text { donija }\end{array}$ & Srbija \\
\hline 2008. & 8,8 & 10,0 & - & - & 12,4 & 17,1 \\
\hline 2009. & - & 9,4 & - & - & 14,3 & 19,2 \\
\hline 2010. & - & 11,8 & 19,1 & - & 17,1 & 20,5 \\
\hline 2011. & - & 13,4 & 24,0 & - & 20,4 & 20,6 \\
\hline 2012. & 16,8 & 16,5 & 24,7 & - & 21,7 & 24,7 \\
\hline 2013. & 15,7 & 15,7 & 28,0 & - & 23,1 & 25,4 \\
\hline 2014. & 16,7 & 18,9 & 28,3 & - & 24,9 & 27,0 \\
\hline 2015. & 22,1 & 17,2 & 31,0 & - & 28,6 & 28,9 \\
\hline 2016. & 20,9 & 23,1 & 33,9 & - & 29,1 & 29,9 \\
\hline 2017. & 23,5 & 23,8 & 34,0 & - & 30,6 & 31,4 \\
\hline
\end{tabular}

Izvor: Izrada autora na temelju Eurostat (3), 2019.

11 Obuhvaća stanovništvo 18-24 godine sa najviše završenim sekundarnim obrazovanjem, a koje nije sudjelovalo u aktivnostima obrazovanja i usavršavanja u protekla četiri tjedna. 
Sve veća orijentacija prema ulaganjima u istraživanje i razvoj, obrazovanju i njegovim produktima bi posljedično trebala rezultirati povećanjem radne produktivnosti. Dostupni podatci ukazuju kako je najveći rast produktivnosti ostvarila Crna Gora, a nakon koje slijede Bosna i Hercegovina te Albanija. Ostale zemlje ostvaruju smanjenje produktivnosti (Tablica 11).

Tablica 11. Rast produktivnosti u zemljama Zapadnoga Balkana u razdoblju 2012.2013. godine $(\%)$

\begin{tabular}{|c|c|c|c|c|c|c|}
\hline $\begin{array}{c}\text { Godina/ } \\
\text { Zemlja }\end{array}$ & Albanija & $\begin{array}{c}\text { Bosna i } \\
\text { Hercegovina }\end{array}$ & Crna Gora & Kosovo & $\begin{array}{c}\text { Sjeverna } \\
\text { Makedonija }\end{array}$ & Srbija \\
\hline 2012. & 3,2 & $-0,5$ & $-5,2$ & - & $-1,3$ & 0,1 \\
\hline 2013. & 12,5 & 1,4 & 3,1 & $-7,9$ & $-1,4$ & $-0,9$ \\
\hline 2014. & 0,5 & 2,3 & $-5,0$ & 6,1 & 1,9 & $-6,3$ \\
\hline 2015. & $-2,4$ & 1,9 & 0,9 & 13,2 & 1,5 & 0,2 \\
\hline 2016. & -3 & 5,8 & 1,8 & $-6,8$ & 0,4 & $-2,2$ \\
\hline 2017. & 0,6 & 1,3 & 2,4 & $-3,7$ & $-2,1$ & $-0,7$ \\
\hline
\end{tabular}

Izvor: Izrada autora na temelju Svjetska banka (5), 2019.

Međutim, kada se sagleda prosjek cijeloga razdoblja, situacija je još negativnija. Naime, tijekom promatranoga razdoblja samo Albanija, Crna Gora i Kosovo ostvaruju povećanje produktivnosti, dok je u ostalim zemljama ostvaren pad. Također, sagledavanjem prosjeka svih promatranih zemalja, vidljivo je kako ova skupina zemalja, unatoč povećanim ulaganjima u ,suvremene izvore“ gospodarskoga rasta, ostvaruje smanjenje produktivnosti. Ovakva situacija, kao i ostali izazovi i ograničenja identificirani tijekom ovoga istraživanja, predstavljaju temelj za definiranje i implementaciju složenih strukturnih promjena, kojima će se pokrenuti daljnja konvergencija ove skupine zemalja te pružiti potpora njihovoj daljnjoj integraciji u EU.

\section{ZAKLJUČAK}

Provedenim istraživanjem pružena je sinteza teorijskih aspekata konvergencijskih procesa te je utvrđeno kako konvergencija predstavlja složeni i dugotrajni proces sustavnoga smanjivanja razvojnih razlika između regija te je prepoznata kao jedan od ključnih ciljeva europskog integracijskog procesa. Pritom, posebna pažnja je posvećena područjima sa problemima i razvojnim ograničenjima, a među koje svakako ulaze i zemlje Zapadnoga Balkana. Središnji dio ovoga rada predstavlja kvantitativna analiza procesa realne konvergencije u zemljama Zapadnoga Balkana, provedena na temelju indikatora gospodarskoga rasta, indikatora tržišta rada i životnoga standarda te „razvojnih“ indikatora, a čime su ostvareni definirani ciljevi istraživanja. Sagledavanje indikatora gospodarskoga rasta upućuje kako ove zemlje, uključivanjem u europske integracijske procese 
i zbog pritisaka globalizacije, ostvaruju pozitivne trendove u razinama BDP-a per capita i stopama gospodarskoga rasta, a što bi trebalo imati pozitivne učinke na tržište rada te unaprjeđenje životnoga standarda. Iako indikatori tržišta rada i životnoga standarda upućuju na pozitivne trendove, razine nezaposlenosti, minimalne plaće, stanovništvo pri riziku od siromaštva i socijalne isključenosti te izdvajanja za zdravstvo se još uvijek nalaze na osjetno nižim razinama u usporedbi sa EU prosjekom. Postojeća situacija predstavlja izazov za nositelje gospodarske i političke moći u definiranju sveobuhvatnih politika i strukturnih reformi u cilju osiguranja uvjeta za ostvarenje konvergencije prema razvijenim zemljama članicama EU, a što poseban naglasak stavlja na skupinu razvojnih indikatora. U ovome području analizirane zemlje ostvaruju pozitivne trendove u vidu povećavanja ulaganja u istraživanje i razvoj te unaprjeđenja svih aspekata obrazovanja. Međutim, navedena ulaganja nisu u potpunosti i kvalitetno stavljena u funkciju poboljšanja gospodarskih performansi, a što je najočitije iz smanjivanja radne produktivnosti. Na temelju provedenoga istraživanja moguće je utvrditi pozitivan smjer odvijanja procesa realne konvergencije u zemljama Zapadnoga Balkana, uz još uvijek prisutna osjetna zaostajanja za razinama EU. Prepoznata ograničenja i s njima povezani izazovi predstavljaju temelj definiranja i implementacije modela dinamičkoga upravljanja strukturnim promjenama, čime će se potaknuti strukturne promjene te omogućiti daljnje odvijanje procesa konvergencije te ostvarenje održivoga članstva u EU, a što je određeno kao ključni strateški cilj ove skupine zemalja. Iz svega navedenoga proizlazi znanstveni doprinos rada. Buduća istraživanja ove tematike bi se trebala usmjeriti na dubinsku analizu dosadašnjih učinaka integracijskih procesa na implementaciju koncepta dinamičkoga upravljanja strukturnim promjenama u ovim zemljama te daljnji napredak procesa konvergencije i ostvarivanja kohezije.

\section{LITERATURA}

1. Bilas, V. (2005), Konvergencija tranzicijskih zemalja prema Europskoj uniji, Ekonomski pregled, Vol. 56, No. 3-4, str. 221-238.

2. Bojrkstenn, N. (2000), Real convergence in the enlarged euro area: a coming challenge for monetary policy, Bank of Finland, Economics Department Working Papers 1/2000, dostupno na: https://papers.ssrn.com/sol3/papers. cfm?abstract_id=233888, (pregledano 20. kolovoza 2019.)

3. Bogunović, A. (2001), Ekonomske integracije i regionalna politika, Fakultet ekonomije i turizma 'Dr. Mijo Mirković' u Puli, Ekonomski Fakultet u Zagrebu i Mikrorad d.o.o., Zagreb

4. Bogunović, A. i Vukoja O. (2008), Integracije, ekonomski rast i konvergencija, zbornik radova znanstvenoga skupa „Poljoprivreda i privredni razvoj“, Ekonomski fakultet Zagreb, Republika Hrvatska 
5. Bongardt., A., Torres, F., (2013), Convergence in the EU, Intereconomics Review of European Economic Policy, Vol. 48, No.2, str. 72-92.

6. Drastichova, M. (2012), The relations of real and nominal convergence in the EU with impacts on the euro area participation, Central European Review of Economic Issues, Vol. 15, str. 107-122.

7. Dekabank (2019), dostupno na: https://www.deka.de/deka-group, (pregledano 26. kolovoza 2019.)

8. Detken, C., Gaspar, V. i Noblet, G. (2004), The New Member State Convergence and Stability, Europska središnja banka, Frankfurt na Majni, Njemačka

9. Europska komisija (2019), dostupno na: https://ec.europa.eu/info/business-economy-euro/economic-and-fiscal-policy-coordination/eu-economic-governance-monitoring-prevention-correction/european-semester/framework/europe-2020-strategy_hr, (pregledano 25. srpnja 2019.)

10. Eurostat (1) (2019) dostupno na: https://appsso.eurostat.ec.europa.eu/nui/ show.do?dataset=cpc_pslm\&lang=en, (pregledano 25. srpnja 2019.)

11. Eurostat (2) (2019) dostupno na: https://ec.europa.eu/eurostat/tgm/table. do $?$ tab $=$ table $\&$ init $=1 \&$ language $=$ en $\&$ pcode $=$ tps $00155 \&$ plugin $=1, \quad$ (pregledano 25. srpnja 2019.)

12. Eurostat (3) (2019) dostupno na: https://appsso.eurostat.ec.europa.eu/nui/ show.do?dataset $=$ cpc_pseduc\&lang $=$ en, (pregledano 25. srpnja 2019.)

13. Eurostat (4) (2019) dostupno na: https://appsso.eurostat.ec.europa.eu/nui/ show.do?dataset $=$ cpc_psilc\&lang=en, (pregledano 25. srpnja 2019.)

14. Eurostat (5) (2019), dostupno na: https://ec.europa.eu/eurostat/tgm/table. $\mathrm{do} ? \mathrm{tab}=$ table $\&$ init $=1 \&$ language $=$ en $\&$ pcode $=$ tps00203\&plugin $=1, \quad($ pregle dano 25. srpnja 2019.)

15. Za EU - Eurostat (6), dostupno na: https://ec.europa.eu/eurostat/tgm/table. $\mathrm{do} ? \mathrm{tab}=$ table $\&$ init $=1 \&$ language $=$ en $\&$ pcode $=\mathrm{t} 2020 \_10 \&$ plugin $=1$, $\quad($ pregledano 25. srpnja 2019.)

16. Eurostat (7), 2019, dostupno na: https://ec.europa.eu/eurostat/tgm/table. $\mathrm{do} ? \mathrm{tab}=$ table $\&$ init $=1 \&$ language $=$ en $\&$ pcode $=$ tps $00155 \&$ plugin $=1, \quad$ (pregledano 25. srpnja 2019.)

17. Eurostat (8), 2019, dostupno na: https://ec.europa.eu/eurostat/statistics-explained/index.php/People_at_risk_of_poverty_or_social_exclusion, (pregledano 25. srpnja 2019.)

18. Eurostat (9) (2019), dostupno na: https://ec.europa.eu/eurostat/tgm/table. $\mathrm{do} ? \mathrm{tab}=$ table $\&$ init $=1 \&$ language $=$ en $\&$ pcode $=\mathrm{t} 2020 \_40 \&$ plugin $=1, \quad($ pregledano 25. srpnja 2019.)

19. Eurostat (10) (2019), dostupno na: https://ec.europa.eu/eurostat/tgm/table. $\mathrm{do} ? \mathrm{tab}=$ table \&init $=1 \&$ language $=$ en $\&$ pcode $=\mathrm{t} 2020 \_41 \&$ plugin $=1$, (pregledano 25. srpnja 2019.) 
20. Eurostat (12) (2019), Archive: BDP na regionalnoj razini, dostupno na: https:/ec.europa.eu/eurostat/statistics-explained/index.php/Archive:BDP na_regionalnoj_razini, , (pregledano 29. kolovoza 2019.)

21. Eurostat (13) (2019), dostupno na: https://ec.europa.eu/eurostat/tgm/table. $\mathrm{do} ? \mathrm{tab}=$ table $\&$ init $=1 \&$ language $=$ en $\&$ pcode $=$ tec $00114 \&$ plugin $=1$, (pregledano 29. kolovoza 2019.)

22. Islam, N. (2003), What have We Learnt from the Convergence Debate?, Journal of Economic Surveys, Vol. 17, No. 3, str. 309-362.

23. Jacobsen, H. et. al, (2004), Economic, Political, Institutional as well as Social Risks and Opportunities of EMU Enlargement, Ezoneplus Working paper No. 22, dostupno na: http://www.ezoneplus.org/archiv/ezp_wp_22.pdf, (pregledano 29. kolovoza 2019.)

24. Jovančević, R. (2005), Ekonomski učinci globalizacije i Europska Unija, Ekonomski fakultet Zagreb, Mekron promet, Zagreb.

25. Kandžija, V. (2003), Gospodarski sustav Europske unije, Sveučilište u Rijeci, Ekonomski fakultet, Rijeka

26. Kandžija V., Cvečić, I. (2008), Makrosustav Europske unije, Sveučilište u Rijeci, Ekonomski fakultet Rijeka

27. Kandžija, V., Cvečić, I. (2010), Ekonomika i politika Europske unije, Sveučilište u Rijeci, Ekonomski fakultet, Rijeka

28. Kersan-Škabić, I., Mihaljević, A. (2010), Nove zemlje članice EU i EMU - Konvergencija i financijska kriza, Ekonomski vjesnik, Vol. 23, No. 1, str. 12.-26.

29. Kesner-Škreb, M. (2006), Kriteriji konvergencije, Financijska teorija i praksa, Vol. 30, No. 4, str. 405-407.

30. Kowalski, P. (2003), Nominal and Real Convergence in Alternative Exchange Rate Regimes in Transition Countries: Implications for the EMU Accession, Center for Social and Economic Research, dostupno na: https://case-research.eu/upload/publikacja_plik/1708281_270.pdf, (pregledano 29. kolovoza 2019.)

31. Krugman, P. (1993), Adjustment and Growth in the European Monetary Union, Cambridge University Press, Cambridge

32. Kulhanek, L. (2012), Real convergence in Central and Eastern European EU member states, Munich Personal RePEc Archive, Munich University Library, dostupno na: https://mpra.ub.uni-muenchen.de/39822/1/MPRA_paper_39822.pdf, (pregledano 29. kolovoza 2019.)

33. Lavrač, V., Žumer, T. (2003), Accession of CEE countries to EMU: Nominal Convergence, Real Convergence and Optimum Currency Area Criteria, Bank of Valletta Review, No. 27, str 13-34.

34. Marelli, E., Signorelli, M. (2010) Institutional, Nominal and Real Convergence in Europe, Banks and Bank Systems, Vol. 5, No. 2, str. 140-155. 
35. Milardović, A. (2000), Zapadni Balkan: pojam, ideje i dokumenti o rekonstrukciji Balkana u procesu globalizacije, Pan Liber, Osijek, Zagreb, Split

36. Monfort, F. (2008), Convergence of EU regions - Measures and evolution, European Union Regional Policy, dostupno na: https://ec.europa.eu/regional_policy/sources/docgener/work/200801_convergence.pdf, (pregledano 29. kolovoza 2019.)

37. Moussis, N. (2007), Access to European Union law, economics, policies, European Study Service, European Study Service, Brussels, Belgija

38. Mundell, R. (1997), Currency Areas, Common Currencies, and EMU, American Economic Review, Vol. 87, No. 2, str. 214-16

39. Ott, K. (2003), Pridruživanje Hrvatske Europskoj Uniji (Izazovi ekonomske i pravne prilagodbe), Institut za javne financije i Zaklada Friedrich Ebert, Zagreb.

40. Solow, R. M. (1956). A contribution to the theory of economic growth, Quarterly Journal of Economics, Vol. 70, No. 1, str. 65-94.

41. Svjetska banka (1) (2019) dostupno na: https://data.worldbank.org/indicator/ ny.gdp.pcap.cd, (pregledano 15. kolovoza 2019.)

42. Svjetska banka (2) (2019) dostupno na: https://data.worldbank.org/indicator/ ny.gdp.mktp.kd.zg, (pregledano 15. kolovoza 2019.)

43. Svjetska banka (3) (2019) dostupno na: https://data.worldbank.org/indicator/ SH.XPD.CHEX.GD.ZS, (pregledano 15. kolovoza 2019.)

44. Svjetska banka (4) (2019) dostupno na: https://data.worldbank.org/indicator/ GB.XPD.RSDV.GD.ZS, (pregledano 15. kolovoza 2019.)

45. Svjetska banka (5) (2019), dostupno na: http://documents.worldbank.org/ curated/en/351461552915471917/pdf/135370-Western-Balkans-Labor-Market-Trends-2019.pdf, (pregledano 15. kolovoza 2019.)

46. Tomljanović, M. (2017), Ulaganje u istraživanje i razvoj-čimbenik prilagodbe zemalja Zapadnoga Balkana gospodarstvu EU, Sveučilište u Rijeci, Ekonomski fakultet, Rijeka, Republika Hrvatska, doktorska disertacija.

47. Ugovor o Europskoj uniji (1993), dostupno na: http://www.mvep.hr/custompages/static/hrv/files/pregovori/111221-lisabonski-prociscena.pdf, (pregledano 29. kolovoza 2019.)

48. Ugovor o funkcioniranju EU (2007), dostupno na: https://eur-lex.europa.eu/ legal-content/HR/TXT/HTML/?uri=CELEX:12016ME/TXT, (pregledano 29. kolovoza 2019.)

49. Varblane, U., Vahter, P. (2005), An Analysis of the Economic Convergence Process in the Transition Countries, Tartu University Press, University of Tartu, Faculty of Economics and Business Admministration, Tartu

50. Vujčić, B. (2003), EURO-Europska monetarna unija i Hrvatska, Masmedia, Zagreb 


\title{
Marko Tomljanović, PhD
}

University of Rijeka, Faculty of Economics and Business Rijeka, Rijeka, Croatia marko.tomljanovic@efri.hr

\section{REAL CONVERGENCE IN THE WESTERN BALKAN COUNTRIES}

Received: August 23, 2019

Accepted: December 15, 2019

Review

\begin{abstract}
Convergence is one of the key priorities of European economic integration, with the aim of reducing development disparities between regions The research problem stems from the economic, political, social and other constraints in the Western Balkan countries, which are slowing down their progress and the achievement of the full EU membership, which is defined as their key long-term strategic goal. Conducted research aims to scientifically analyse and present the theoretical foundations of convergence processes and to analyse the state of real convergence achieved so far in the Western Balkan countries. The conducted research identified positive developments in the observed countries in the form of an increase of GDP per capita, positive dynamics of economic growth and an increasing orientation toward modern drivers of economic growth. However, these countries are still facing with problems related to the labour market, living standards and productivity gains. The current situation presents a challenge for holders of economic and political power in defining comprehensive policies and structural reforms in order to secure the conditions for further convergence towards developed EU Member States.
\end{abstract}

Keywords: $E U$, real convergence, Western Balkan countries

JEL: F15, F63 